reins right side of head congested; right mastoid muscle rigid; pain on pressure of position of vein which passes through the posterior condyloid foramen; dense stupor; pulse slow and feeble. Constipation.

Operation.-General anæsthsia; thorough antisepsis; skull trephined one and one-half inches above and one-half inch behind the centre of the external meatus; dura-mater opened; dura-mater and piamater congested; a hollow needle was inserted toward the eminence of the petrous bone; pus found, three-fourths inch deep; the skull was at the same operation again trephined in the base, just above the osseous boundary of the external meatus. involving the squamo-petrosal suture; the abscess was reached; irrigation: chicken-bone drainage tube; antisepic rlessings. Recovery.

Case 10.4.-Archires of Otology. September. 1889. Treated by William McEwen of Glasgow. Male, age seventeen. Left ear. Chronic otorrhoa; unconscious; weak and slow pulse; optic neuritis; nearly moribund ; carious sinus into mastoid cells; vomiting; pain in head; chills. Left hemiplegia-

Operation.-Mastoid opened; carious matter expelled; lateral sinus exposed, on which he found granulatious: the bone was then perforated further Jack than the groove for the lateral sinus; pus escaped from over the cerebellum; chicken-bone drainage tube; antiseptic dressings. Recovery.

Case 105.-British Medical Journal, November 8, 1879. Treated by Thomas Barr of Glasgow. Male, age seventeen. Left ear. Chronic otorrhœa ; vomiting; pain in head; stupor; tremors; convulsions. Death.

Autopsy.-Left temporo-sphenoidal lobe adherent to the bone beneath. Abscess in temporo-sphenoidal lobe. Encapsulated. Two carious openings in petrous bone. One in the tympanic roof; the other in the groove for the lateral sinus, communicating with the mastoid cells.

Case 106._Glastow Medirerl Jourmal, July, 1880. Treated by Thomas Barr of Glasgow. Male, age fourteen. I eft ear. Chronic otorrhoea; vomiting; pain; coma; spasmodic contraction of flexors of al'ms and legs. Death.

Autopsy-Abscess in temporal lobe. Drum-head gone. Polypus in tympanum. Stapes gone.

Cass 1\%:-Glastow Medical Journrl, July, 1880. Treated by Thomas Barr. Male, age seventeen. Left ear. Chronic otorrhoea; aphasia; constipation; unconsclousness; paresis of right side; coma. Death

Autopsy.-Abscess in left temporal lobe. Carious fistula in roof of antrum. Carious opening in sig. moid flexnre. Carious opening in posterior upper wall of ex. meatus. All the fistulæ communicated with the mastoid cells.

Case 108.-CHlasgor Ledical Jomenal, July, 1880. Treated by Thomas Barr. Male, age twelve. Left ear. Chronic otorrhea; pain in mastoid and occiput chills; romiting; constipation. Death.

lutops.y.-Pus beneath dura-mater on posterior surface of left petrous bone. The walls of the left lateral sinus were thickened and detached from the bone by underlying pus. Mastoid cells filled with cheesy pus.

Case 109.-Treated by Remmel. Right ear. Chronic otorrhœa. Medium temperature and pulse; pain in head and neck. (Edema and tenderness over mastoid : later, right facial paralysis; œedema of right upper eye-lid; delirium; anæsthesia right half of face; diarrhœa. D Jath.

Autopsy.-Caries of ty.npanum. Thrombus in right lateral sinus. Phlebitis of jugular vein. The thrombus in the lateral sinus extended through the inferior petrosal sinus to the right cavernous sinus, thence through the circular sinus to the left cavernous sinus, which was flled with disorganized clots and pus.

Ca.se 110.-Treated by Taylor. Chronic otorrhoa; delirium; strabismus; diplopia; sudden rise and fall of temperature; retinal veins large and tortous. Death.

Autopsy.-Thrombosis of lateral sinus. Thrombosis and phlebitis of jugular vein. Abscess in lungs. ( $T o$ be continued.)

\section{HYPNOTISM IN ITS RELATIONS TO MEDICAI, JURISPRUDENCE.}

Read before the Medico-Legal Society of (hicago, October 1, 1892.

$$
\text { BY MR. E. O. BROWN, }
$$

OF THE CHICAGO BAR.

I cun hope to do little more than call your attention to the importance of the interesting subject which I have undertaken to discuss to-night. No one can realize better than $\mathrm{I}$, how entirely inadequate my presentation of it must be, because of the limitations of time, and opportunity for preparation, in the midst of occupations which are continuously engrossing. If I can awaken an interest which shall result in a discussion between my learned brethren of the two faculties here present, I shall have accomplished quite as much as I dare expect.

That the subject $i$ an interesting one, I think no one can truly deny. Within a little more than ten years an entirely new factor has been introduced into the problem of legal responsibility. A physical, or perhaps, more properly speaking, a psychological state, with which neither the laws, nor the lawmakers of any people have concerned themselves; the existence of which, indeed, they have never seemed to know, has been discovered to exist. It is a state which is neither sanity nor madness, and neither sleepirg nor waking-as these terms are generally used. In it, a person must be considered as irresponsible for his words, his thoughts and his acts; and yat, in it he has all the exterior characteristics of a person fully awake, reasonable, and master of himself. This is startling enough by itself, and to deal with it properly, would require machinery very different from that by which our courts now endeavor to determine questions of sanity and insanity. When to this proposition is added the further one, that a person in the hypnotized state of which I speak, becomes frequently an automaton in the hands of his hypnotizer, and that an action, good, bad or indifferent, suggested by the hypnotizer to the subject, will, in a large proportion of cases, be carried out by the subject after waking, however abhorrent it may be to his natural character, and carried out frequently after an interval of many days, weeks, or even months, the imagination itself finds it difficult to grasp all the complications in social and legal relations to which it may give rise.

How recent is all the knowledge which we have upon the possibilities of the hypnotio state, is a fact within the personal observation of all of us here. 
When I was in college, only twenty-five years ago, I remember well that I knew both a natural (as the term was then used) somnambulist, and one in whom the state was regularly induced for therapeutic purposes.

The first was a class-mate, who upon many occasions, in his sleep performed strange and fantastic actions, which became widely known among his college friends. A peculiarity often remarked upon, was his complete recollection during one sleep-walking adventure of that which had taken place in a previous episode of the same nature, and his complete forgetfulness during his normal waking state of either. But $I$ do not remember that even in a community of students, who would naturally be supposed to be interested in such matters, the how or why of this double personality-for in effect it was nothing else-was ever discussed.

The second case was much more notable, and did provoke, among the limited circle which was acquainted with it, much wonder and curiosity. even, I think, found its way into the work upon mental philosophy of the late Dr. Wayland, President of Brown University.

A young girl in Providence, named Winsor, had suffered through accident a serious injury to her spine. She became bedridden, and for a number of years, and until her death, remained so. At first she suffered terribly from inability to sleep, and although sometimes falling into a comatose condition, anything like true rest was impossible to her, until it was found by her physician, that certain manipulations by himself on or about her head, removed the nervous restlessness which was always present, but increased at the coming of night-and threw her first into a more cheerful and quiet state of mind and body, which passed afterward during the evening, into a comparatively quiet sleep. But almost contemporaneously with this discovery and its practical application, came strange mental and physical phenomena. The right hand and arm of Miss Winsor were, in her normal state, paralyzed. In the condition into which she was thrown by the doctor's manipulations (a condition which is now familiar enough to investigators and experimenters in hypnotism under the name of the "hypnotic trance," or sometimes "induced somnambulism"), this arm and liand became capable of use and, indeed, the more efficient of her members. Another strange thing developed itself. Her manner and disposition changed in the hypnotic state. Her capacity for various kinds of handicraft was wonderfully increased in this inluced condition over that which she possessed in her normal state. She seemed to have greater vigor, vitality and energy; and in this induced state, and for many hours during each evening, she would draw, make fancy work, and do many other things for which she felt no disposition and no sufficient strength during the day. And finally she developed a persomality in the somnambulistic state as distinct as possible from that of her daily life. Of all the acts done and experience suffered during the day she had a perfect memory nightly; and she also recollected every thing which had taken place on preceding nights and in her secondary state-while during the day she was as entirely oblivious of everything which occurred between the times of her being put into the hypuotic state and her waking in the morning, as healthy persons are of that which takes place about them while they are in a sound sleep.
This case was one which lasted through many years; the physician in attendance being kept by it, to the detriment of his own health, constantly at home, for it was found that it had a very serious effect upon the condition of his patient if any other physician attempted to fill his place, and induce the hypnotic or somnambulistic condition, which had become to the patient her only method of rest.

I have spoken at length of this case, which came under my own immediate and very frequent observation, simply to emphasize the difference between the condition of medical knowledge upon the subject then and now. The condition of Miss Winsor was a marvel-hardly credited by those unfamiliar with it. Frequent charges of imposture were made against her, and her physician, whose devotion to his patient through long years is entitled to the greatest possible admiration, was viewed, because of his simple narration of undeniable facts, with suspicion and dislike by some of his professional brethren, who should have knowñ far better.

But all this is changed. To-day it is as easy to refer the case of Miss Winsor to a well-known class or category of pathological conditions, as that of an ordinary fever patient. All the peculiarities of her state have been duplicated and reduplicated hundreds, and indeed thousands of times. That which was in her case the result of disease, has been shown by experiment to be capable of production in persons of normal health, but of peculiar sensitiveness to so-called hypnotic influence.

And the hypnotic state into which such persons have been thrown has been analyzed, tested, and one might almost say dissected-not, of course, to anything like a complete knowledge of the subject, but to a wonderfully increased and developed one.

Twenty years ago the world did not believe in hypnotism. In 1866 Dr. Liebault, today one of the most noted names in all matters of this nature, published a book called "Sleep and Kindred States of Being," in which he set forth certain theories, which have since been almost universally accepted-and but six copies were sold. There had been, of course, for an hundred years, an acquaintance by medical men with the so-called phenomena of animal magnetism. The French Academy of Sciences published a report concerning Mesmer-partly charlatan, partly mystic and partly scientist-but there was so much during the years which followed of undeniable quackery, mixed with the so-called mesmeric, or magnetic phenomena, that it was not until such men as Charcot, Bernheim, Beaunis, Richer, Richet, Janet and others known to the world to be the greatest of living neurologists, took up the subject, and eagerly pursued the fascinating inquiries that it suggested, that enough unprejudiced and unashamed interest was awakened in other scientific minds to bring about any considerable increase of definite knowledge upon the subject. But to day, although it is in France particularly that the study of hypnotism is pursued systematically, and its therapeutic uses acknowledged and enforced, yet to the men who are constantly carrying on and pressing the investigation at Nancy and at Paris, at Havre and Bordeaux, the whole medical world, as I understand, looks, at least with respect, if not with deference; and there is little skepticism as to the results which they have achieved, and but iittle dissent from the propositions upon which they agree.

It is true that great differences of theory exist be- 
tween the so-called rival schools of Paris and of Nancy. Dr. Charcot and his colleagues at ParisJanet, Binet, Ribot and others, hold that hypnotism is a pathological condition produced by peculiar and extraneous action upon the nerves, and style it abnormal. The doctors at Nancy, upon the other hand, represented by Bernheim and Liebault, and other great names, entertain the view that there is nothing abnormal about hypnotic sleep; that it is normal sleep hypnotically produced, and produced entirely by suggestion. They say that hypnotism is not a pathological condition, but a psychological state, and that all the extraneous machinery used by the Paris school in inducing it are mere signs to the patient of what is expected of him, and that the fact that hystero-epileptic patients are more easily hyprotizable than healthy persons, means simply that they are more suggestible.

So as to the value of hypnotic suggestion in curing diseases, trifling or serious; and as to the matter with which my paper is more particularly concerned, criminal suggestions, or suggestions affecting legal rights and relations, there is serious and grave controversy between men of equal repute, and of equal opportunities and capacities for observation. I do not by any means intend to venture to-night upon a discussion of these disputed questions. I am not so presumptuous as to consider my opinion valuable to this company, nor is it within the scope of the purpose with which I prepared this paper. But, as I have above indicated, certain things are agreed upon by these mentioned investigators. And these things upon which there is no longer controversy, are sufficient to establish the importance of the suggestions which I purpose to make concerning the relation of hypnotism to medical jurisprudence.

The propositions then upon which there may be said to be substantial agreement, are concisely, as I understand it, as follows:

By various methods, most of them, at least, involving some fixation of vision, and resulting in nervous fatigue, coupled with more or less authoritative actions or command on the part of the hypnotizer, a very considerable proportion of persons upon whom the experiment may be tried without their resisting it, can be thrown into a hypnotic state; that is, into a state of induced somnambulism, in which, like the Winsor girl, of whom I have spoken, they can think, speak and act-their eyes are open, and they present the appearance of a waking person, and yet to a greater or less extent they are irresponsible and, apparently, indeed, of a more or less different personality from their usual and normal one. This state is induced in the subjects experimented on or therapeutically treated at the hospital of Ia Salpetriere, at Paris, simply by directing the attention of the eyes by an upward and inward squint upon some bright object held slightly in front of and above them, while a few passes of the kind familiar to most of us as magnetic, or mesmeric, are made on or in the vicinity of the head-or else, pressure is used upon the eyeballs or at other points on the head.

At Nancy, on the other hand, the state is generally induced by a rapid rotary and alternating motion of the patient's fists before the eyes, coupled with extremely imperative commands to sleep.

It is only a portion of the persons upon whom the attempt to hypnotize is made who can be to any extent brought under its influence, even though they profess to be willing; and it is a much smaller proportion who are, in the language, of the French savants "tres bonnes somnanbules" that is, to a high degree "suggestible"; and therefore, the persons to whom the criminal suggestions are made of which I purpose to speak, could be of much danger.

Prof. Liegeois, of the law department of the University of Nancy, and an eminent authority upon this matter, belonging too to the school of investigators which sees the most danger in this matter of possible criminal suggestion, calculates the number as 4 out of 100 in any given community. But, as he well remarks, inasmuch as this in the city of Paris alone means 100,000 persons, the percentage is not insignificant. In certain classes of people, of course, greater amenability to the influences described is to be found than in others. Thus, hystero-epileptic patients are made by the physicians of Paris almost the only subjects of their experiments-so much more readily do they respond, in their opinion, to the suggestions which are made. But it is quite certain, nevertheless-and from this the Paris school does not dissent-that it is by no means necessary in order that a subject may turn out to be "unetres bonne somnambule" that he or she should have any symptoms of hysteria or epilepsy. Women are more susceptible than men; children than adults.

Dr. Berillon, in a recent paper before the Psychological Congress, just held in London, insists that eight out of every ten children from six to fifteer years of age, no matter how robust and healthy, are susceptible of being sent into a profound sleep after the first or second attempt. And this was his conclusion after experiments upon 250 children of both sexes, taken from all classes of society.

After one successful attempt has been made by a given operator upon a given subject it is constantly easier, if the subject still continues to submit to the experiment, for the hypnotizer to induce the desired condition. And, in a very short time, if the person is a good subject, very slight suggestions of what was: originally necessary to produce the hypnotic condition, will be sufficient to throw the patient into $a$ trance.

And for this result, with those who have been often before treated, it has been thoroughly proven at La: Salpetriere that fifteen seconds are sufficient. Or rather the inducement of the state is instantaneousa quick command-a clap of the hands, is sufficient. The quarter of a minute will suffice for the production of the hypnotic state, the suggestion of some act thereafter to be performed, and the awakening. The awakening of the subject is generally effected by blowing upon the eyeballs.

Many strange things, not within the purview of this paper, can be predicated of this hypnotic state. But that which I am about to set forth, although I would scarcely dare to call it in the bewildering variety of results which have been attained-the strangest, is the one to which alone I would direct your attention. It is that the hypnotizer can, during the continuance of the hypnotic state in his patient, suggest to him the commission of a given act, hours, days or weeks, indeed, ahead, and that suggestion becoming a fixed idea will, in the case of the good subject, certainly be committed by him after his awakeningas surely as a stone dropped from the hand will fall to the ground. Nor is the state in which he performs the act that of apparent somnambulism. In the 
hypnotic state proper, or in the ordinary hypnotic state, the subject is passive to a greater or less extent: Although, as I have said, he can think, speak and act, he thinks, speaks and acts mostly by excitation from without. He has more or less the appearances familiar in somnambulists. But the awakening seems to be thorough. Before that time arrives for the commission of the suggested act, he is apparently in an entirely normal state. But when he commits the act, and thus realizes the suggestion which has been made, one or several hours, or several days it may be, in advance,-although he must certainly be, so the authorities agree, again in a hypnotic state in the largest sense of the word,-he has, for all who see him walk and speak and act, the appearance not of a somnambulist, but of a man fully awake. Nor will the person committing the act, until he is again placed in the hypnotic trance, remembar that any suggestion has been made to him. He may strenuously deny it-all that he may know is that he feels toward the commission of the act an absolutely irresistible impulse.

I have sufficiently indicated, I think, by this statement as to the conditions which bring about, and which follow from the hypnotic trance, the ways by which it may touch in many points, legal and social relations. It is true that in France, where this subject of the relations of hypnotism to medical juris. prudence have almost solely been treated, the dispute waxes hot as to how far actual crimes of a serious character have been or are likely to be, the result of criminal suggestion made by a hypnotizer upon his willing or unwilling subject. But all the authorities from Charcot down agree as to the possibility, and admit a certain danger-how great that danger may be, is the only point concerning which they differ.

The school at Nancy are inclined to a pessimistic view of the matter; they of Paris, to a much more cheerful opinion. Certain it is that criminal suggestions have been made to many of the subjects of the professors and doctors at Nancy, which have been in appearance carried out to the letter, precaution, of course, having been taken against actual bad results.

Thus, one patient of good character was caused, by suggestion, to place the muzzle of a revolver close to her mother and fire upon her-not knowing that the pistol was not loaded, and having every reason to suppose that it was. So too, a powder, which a patient was told was a poison, was administered by him to his aunt; and numberless cases of small theft for the purpose of experiment have been suggested, and in every instance carried out. But Charcot and the Parisian school rather scoff at the value of these experiments. They by no means suggest imposture or simulation-the character of the experimenters and the nature of the experiments entirely forbid this; but they call these eriminal actions, "laboratory crimes," and insist that they bear but little resemblance to actual ones. The arguments which they use to sustain this proposition, are, after all, somewhat obscure. It seems to me that there is in them a suggestion that they are afraid that adhesion to the propositions advanced by the Nancy school concerning them would unduly alarm the public. And yet, it is hard to say, so strange is the action of the human mind, conscious or unconscious, that the lingering knowledge that things are not what they seem to be, does not remain in the hypnotic subject, as the Parisian doctors urge.
Professor Baldwin who has recently visited La. Salpetriere and Nancy, and written most interesting letters therefrom to the New York Nation, says. that repeated experiments at Nancy have shown that a man to whom the suggestion has been made in a hypnotic state will stab a covered figure in bed, which has been represented to him as a living man, and which he believes to be so. The doctors at Nancy say if their confreres at Paris do not believe that this criminal suggestion would be equally efficacious, if the stuffed figure were a real man, let some one of them take the place of the stuffed figure. According to Prof. Baldwin, the Parisian doctors reply that until the jealousy of them by the Nancy school grows less, they must respectfully decline the experiment.

But, seriously, it is the amount, and not the reality of the danger concerning which the doctors disagree; and in the matter of lesser crimes, such as offenses against female virtue, smaller thefts, and particularly the bearing of false witness or perjury, it is admitted by all that the danger is very real. Especially is it urged by Dr. Berillon, the editor of the Revue de. l'Hypnotisme, although a stanch member of the Paris. school, that children, from their very great suggestibility can easily be made, in the hands of conspirators, the most dangerous of falsewitnesses. It could easily be sen too, how in such matters as testamentary wills the ends of justice and right may be defeated. Undue influence-a familiar term to our law, gains a new meaning in the light of what has. been set forth.

And here I wish to make a digression for a. moment. It may be that there are those here to whom hypnotism and the researches which have. been made concerning it, by the ablest investigators, physiological and psychological, of the world, are not well known, and who look in a paper like this for some argument that hypnotism and its results. as shown in the subjects experimented upon, are not simulation and imposture. I wish to say to them that I do not purpose to make any such argument, I have simply assumed it as indubitable; nor have I thought it at all necessary to cite cases, or advancs. proofs, of which the literature of the subject is full. In the present state of medical science, I should have no fear that any physician would here advance the contrary proposition. But I am not so sure of the lawyers, if their attention has never been called to: the phenomena of which I have been speaking-for. the law, I shall take occasion to say again in my paper, is not progressive, and lawyers are far from open-minded, as a rule, to the marvels of science.. The fact is, that years ago the theory of simulation upon the part of the subjects of hypnotism was given up by all intelligent critics. All sorts of surgical operations have been performed where hypnotism has taken the place of anæsthetics. Muscular conditions absolutely impossible in the normal state have been induced in thousands of cases. Cures by suggestion at La Salpetriere and at Nancy, and indeed all over the world, have been made in myriads. of cases. Indeed, the characteristic look of the hypnotic patient would, if the up-rolling of the eyeballs were simulated, imply nothing less than a world-wideconspiracy. But all bodily symptoms excluded, a complete proof would be afforded by the ever growing improbability that thousands of persons in hundreds of places, guiltless of theories, and unac- 
quainted with each other, could build up by their several acts of conscious or unconscious deceit a large and consistent body of psychological results. To any person who doubts the reality of the phenomena which the various hypnotists of the world-many of them among its most famous and eminent physicians, agree are the concomitants of the hypnotic trance, $I$ can only say that I advise him to make some acquaintance with the present literature of hypnotism, say in the proceedings and journals of the Society of Psychical Research, that wonderfully pains-taking and scientifically-minded body of which the Honorable Arthur Balfour is a leading member, and of which Professor James, of Harvard University, has written so enthusiastically in a late number of the Forum.

To return to the connection of hypnotism with medical jurisprudence, it is not only in connection with "laboratory crimes," such as I have spoken of, that in Franoe the discussion of criminal suggestion has been waged. You, doubtless, all remember how, without success, the defense of criminal suggestion was made in the case of Gabrielle Bompard, the accomplice of Eyraud, in the terrible murder of Gouffe, -Professor Liegois still insists that there was grave injustice in that trial. However, that may be, the doctrine has not always been so unsuccessfully put forward. According to the system in use in Francemuch better arranged than here for determining the responsibility or irresponsibility of persons accused of crime, many cases of automatism, so-called, natural or suggested, have beeu referred to the properly authorized medical officers in charge of various departments of the Police of Paris and of France, and in several reported cases, their report having fully established to the satisfaction of the court the abnormal state of the prisoner when the offense was committed, he was discharged.

It is not strange that in a country in which hypnotism received its first scientific investigation, and where research and experimentation have gone to such lengths as they have in France, there should have been much more thought and said and written of its possible relations to legal rights and judicial proceedings, than in any other country in the world, And there is another reason, too, for this. It is un doubtedly true that a larger proportion of the mercurial and nervous and excitable French people is amenable to hypnotism and hypnotic influences, than of more phlegmatic races. And I must confess that up to the present time there does not seem, so far as the record of legal proceedings in England and America goes, much occasion for that alarm which has manifested itself among the ablest physicians and lawyers of France, in the matter of possible criminal suggestion. But it is impossible that to France alone and to French physicians alone the scientific inquiry into hypnotism will be long con. fined. Already in this country we have, not whole schools of physicians indeed, but individual (and very clever) men eagerly pursuing this line of in. quiry. The knowledge of the possibilities which lie within the range of induced somnambulism will soon make rapid progress among the masses of the people, and it can hardly be expected that we shall enjoy, ther fore, long in the future, an immunity such as now seems to exist from the dangers which have been so forcibly suggested in France. Nor is this a thing to be regretted or deprecated, for the knowledge which is to be gained is knowledge, after all, of the truth, which in the end can injure no one. If hypnotism can be used for bad purposes, it can and undoubtedly will be used much more for good ones. There is no powerful and beneficent drug which is not also a poison, with the power of destroying as truly as that of healing. And at all events, whether newly discovered truths are to be welcomed or deprecated, it is necessary to arrange one's life, and to organize society according to them when they are known. And it is but the part of cowardice to say that there are any truths which should not be known.

It will be long, however, I think, before we shall need to attend to any such extreme suggestion as that which has recently been put forward in France by no less an authority than Prof. Liegeois-called by him "moral vaccination." He has seriously proposed that to boards of competent practitioners commissioned by the Government-as in the case of vaccination in this country-all persons, and especially all children, should be brought. If they are found non-suggestible, well and good; but if they can be hypnotized and brought to a profound degree of "induced somnambulism," there should be made to them, in that state, a suggestion that thereafter it shall not be possible for any other person, by any other means, to hypnotize them. For precaution, it is proposed that this shall be renewed from year to year. For such a suggestion that the patient is not to succumb to the hypnotic influence of any other person than the one making to him, or her, this suggestion, has been found to be equally efficacious with any other.

I say that we need hardly anticipate that such a proposition as this will ever be made and considered seriously in our time and environment. But unless the law and its professors are prepared to be justly reproached with that want of adaptability to the changed conditions of life and states of human knowledge which has been too frequently their share in the past, it will be necessary, and that in the near future, to consider carefully the question of the responsibility or the irresponsibility of persons claiming to have been the subject of irresistible suggestion.

It is not in the abstract doctrines of our law that the difficulty will be found; it is in the present conditions of their application. We have seen that spontaneous somnambulism is a highly analogous state to the hypnotic trance; and as to spontaneous somnambulism, there is authority already. in the law for saying that, as the somnambulist does not enjoy the free and rational exercise of his understanding, and is more or less unconscious of his outward relations, none of his acts during the paroxysms can rightfully be imputed to him as crimes. Courts would undoubtedly hold that, considering the abrogation of self-control peculiar to the physical condition of the somnambulist, no moral or legal responsibility could be attached to his actions. And indeed, so far as the law can be said to be formulated at all concerning the criminal responsibility of an insane person-as it was formulated, for example, by Sir James Stephen in his draft of a criminal code for Great Britain-there is found in it a rule which, properly applied, would meet the theoretical difficulties which might arise from the phenomena of hypnotism. An insane person, according to this formulation, is not to be held responsible for an act which he may commit when his mental disease pre- 
vents him either, $a$, from knowing the nature of the act done; or, $b$, from knowing that it is forbidden by law; or, c, from knowing that it is morally wrong; or, $d$, from controlling his own conduct.

In class $(d)$ the hypnotic subject of criminal suggestion would fall. His mental state would prevent him from controlling his own conduct. But, it goes without saying that when a practical application of this rule was sought to be made there would be, under present conditions, and in the present state of the law in relation to expert testimony, -an absolute impossibility of determining to the satisfaction of the public at least, whether in any given case the accused was at the time of any criminal act in the condition named. We know now, how utterly absurd, nay, indeed, how indecent are the scenes in court when the question of responsibility, as depending upon mental condition, is to be decided by a jury. Experts, so-called, who are the retained partisans of one side or other in the controversy, are brought in troops into court, where their testimony is thrown into hotch potch. There is hardly a proposition advanced by one so-called expert that another is not found to deny. The jury are absolutely without any valuable test by which they can determine the respective weight to be given to the different and conflicting witnesses. Those experts who are the most entitled to credit are generally the most modest, and reserved and cautious in their statements. They are, consequently, the favorite target for the insults and abuse of counsel.

Such a flagrant seandal has this come to be in our criminal insanity trials that there are no decent lawyers who do not now deplore the system which prevails. But for all that, they are very slow in suggesting change. It seems as if the spirit in which the English lawyers replied to would be law reformers from Rome 500 years ago-"Nolumus mutare leges Angliæ;" "We do not wish to change the laws of England" live yet in bench and bar. Averse to change as lawyers thus are, it would be useless under our system, by which the body of the law adapts itself slowly and painfully and in adjudicated cases only, to new conditions, to attempt to formulate new rules, or new theories of legal responsibilty, because of the new knowledge we have of hypnotism.

It will only be in contested cases that any departure from, or in addition to present formulas will have their origin. And we may be sure that it will be slowly and painfully enough that any such change will come about.

But, in the practical conduct of all trials which involve an inquiry into mental responsibility, it is not hopeless to look for a change in the immediate future. This change is one extremely needed, and it may be brought about, as I believe, by the vigorous effort of such societies as this. It is a reform which is needed, without reference to the new and perplexing problems which hypnotism may throw upon upon courts and juries, but it is one which the possibility of such problems serves to accentuate and emphasize.

It would only need, in one of our criminal courts, a war of experts upon a subject so little investigated and understood in this country as hypnotism, to cap the climax of the absurdity of such judicial farces as have already been enacted when mental alienation was the subject of discussion.

I propose then, and this is the only practical ap- plication to which I would bring my paper, that some such system as this in regard to expert testimony should be urged upon our law makers. Let each state appoint an Examining Board of genuine experts upon mental and nervous diseases and abnormal states. Certainly, in communities like ours. which support and officer asylums for the insane, it would not be difficult to make such a Board of competent and honorable men. Let one of the duties of that Board be to testify as experts upon any cases submitted to them, for which their compensation should come from the body politic. Let houses of detention be established, to which shall be committed before trial all persons for whom the plea of mental irresponsibility is urged. There let such persons. be examined. Let them there also, should occasion seem to demand it, be thrown into the hypnotic state for examination. Let the examination be made more or less prolonged, according to the necessity of the case, as certified by the Board of Examiners. Then,. after the examination is completed, let the depositions. of these real experts be taken, away from the highly unscientific atmosphere of a criminal trial, but upon direct examination and cross examination. Let these depositions thereafter be used before the caurt to determine the question of responsibility.

By such a plan, it seems to me, we can make a great and urgently needed improvement in the administration of criminal justice, and not only remedy the abuses which now exist, but provide against their further development when into the practical domain of our court trials, and legal investigations, shall come the new and perplexing problems of hypnotisin.

Ur. Sanger Brown :-I can only express the opinion I have formed upon the subject of hypnotism from what I have learned by reading and listening to those who have had experience of the phenomena. I have witnessed many attempts to hypnotize people, but none of them were successful.

Granting, however, that the asserted facts are true, it would seem to me to accord with the evidences of psychology to assume that to be a good hypnotic subject implies instability of the intellectual centers; that is, weak cerebral tissues. For instance, when we are willing to trust a member of our commurity with money, we express our confidence in the high quality of his cerebral tissues; various areas in his cerebral cortex have received certain impressiors, and these have become firmly correlated in a manner which will surely prompt him to act in conformity with the principles of honesty. In this way the various elements of character may be traced out.

Now, it is generally conceded that during childhood and youth these impressions and the correlating connections between them have not yet become quite established, because the tissues have not yet fully developed, and allowances are made by courts of law in such cases. It is also generally conceded that among adults instability of the cerebral centers is much more common in women than in men.

When we wish to induce a person to pursue a certain line of action we attack his cerebral centers. and just in proportion to the vigor of our attack and the stability of the centers will we succeed. We may even dose him with alcohol to temporarily reduce his resistance.

Now, it is well known that by far the largest proportion of the population who are thus open to influence, persuasion or suggestion is found among the women and children, and it is asserted that from this same class comes the hypnotic subject. Without discussing in this place the fine points of difference between what is commonly designated persuasive influence and the phenomena of hypnotism, I wish to assert that in their medico-legal relations they are, in my opinion, very nearly alike, both having an operator and a passive subject; the passivity of the subject depending upon the deficiency of his cerebral tissues in both instances, and the 
law needs to make no special provision for one more than the other.

There is practically no probability that a normal adult can be hypnotized unless he wants to be, and this being the case, I do not think that hypnotism should be accepted by the courts as an excuse for crime.

Judge Richard S. Tuthill:-This is my first evening with this Society, but I intend that it shall not be my last, because I find here an opportunity for instruction that it seems to me should be improved by members of my profession, and more especially by those occupying as 1 do at the present time a judicial position. These questions are not only interesting but they are of intense practical utility, and I think it is the duty of the lawyer and the judge, as well as of the medical man, to study and endeavor to master so far as he can the more practical questions such as have been disdussed to-night.

I would like to say a few words on the subject of expert testimony, to which Mr. Brown referred, and his suggestions as to a remedy for the abuses which prevail in expert testimony in sane and insane cases in our courts, and the legal and moral responsibility of persons charged with crime. I had one quite roted case in which medical men of eminence came on the witness stand and gave very diverse testimony. I allude to the trial of Mrs. Rawson for the attempt made by her upon the life of the lawyer of her husband. I don,t think there was very much difference of opinion among the medical men who testified as to the real condition of the person charged with the crime, but there was a disposition on the part of the jury, which is very often found, to seize at any kind of a chance to reach an acquittal, she being an interesting woman and having sulfered what seemed to the ordinary observer many wrongs and hardships. I do not see how it is possible to adopt the suggestion made by $\mathrm{Mr}$. Brown and have certain witnesses furnished by the state, and say that others shall not testify. Such a thing, it seems to me, would be impracticable if not undesirable. But I think a society of this sort can do a great deal in getting up a proper esprit du corps in the medical and legal profession, so that there shall be a desire on the part of every medical man who goes on the stand to have mastered his subject so that he can speak with an authority that will be recognized, because when there is knowledge and certainty of opinion, I have observed that influence goes with it.

The case of John Redmond, who murdered Dr. Wilder, was tried before me. There was not very much difference of opinion among the medical gentlemen who testified; some said he was insane and the others did not disagree with them, they said that at times he was insane, that is his mind was disordered. There the law comes in and says to what extent this disorder should go to make a man legally and morally unaccountable. It is not every disordered intellect that is acquitted of crime in the law. I think the rule of the law is just. fair and intelligent; it is not every man who is not sane that is to be acquitted and turned at large on the community; it is only where insanity has gone to such an extent that it sweeps away his reason and understanding and he has no more control over himself than a mad dog that he is to be held unaccountable. When Dr. Dewey, who had had charge of John Redmond, came on the stand without fee, which fact I took pains to have brought out before the jury, I had every confidence in his character and intention to tell the truth. I asked him whether he believed that John Redmond at the time he fired the shot which killed Dr. Wilder knew that he was doing a legal and moral wrong, and he said that he did. And the law held him responsible; the jury held him guilty of murder and fixed his penalty at imprisonment in the penitentiary for life. I believe if the gentlemen of the medical profession who are called upon to testify upon this subject would draw that distinction and would insist that although a man may have a disordered intellect, although he may be erratic and have illusions to a certain extent. yet if he knows the difference between moral and legal right and wrong he should be held responsible, there would be fewer of these scandals in the courts, of which Mr. Brown speaks.

Mr. E. O. Brown:-The statement of the Judge rather surprises me that in all civilized countries the condition of things prevails which prevails here. But it does seem to me that the system which prevails in continental countries is worthy of consideration because of the effects it brings about in the examination of mental alienation. My idea, which I tried to express in my paper. is not to limit simply expert testimony, but to have certain experts picked out for the purpose who should be impartial, and that would necessarily limit them. We should not have a system which makes the expert witnesses who are testifying upon matters of scientific investigation, partizans of one side or the other of the controversy. That is the essential part of the proposition which I made. It seems to me it is possible to disjoin the investigation of a question of fact or occurence from the investigation of the mental condition of any given person. As to the rule which the Judge lays down about insanity, it strikes me that he is a little inconsistent; if the question is only whether a man knows whether his action is right or wrong, then the other test which he suggested of an uncontrollable impulse, must be excluded because insane persons do know that a thing is wrong sometimes when they are unable to control their conduct and not do the thing. The Judges in England stated to the House of Lords, in the McNaughton case, that the true test was whether the criminal knew the difference between right and wrong. But that has since been much departed from here and in England, and everywhere because the question is, sometimes, whether knowing a thing to be wrong the person committing the crime could control his own action.

Dr. Archibald Church :-During the past three years, practically without any definite intention on my part, I have had more or less to do with this subject of hypotism and have in a rather desultory way experimented with it at not infrequent intervals. I would say that the proportion of people hypnotizable is less than that laid down by the essayist of the evening upon the statement of European authorities. have been unable to hypnotize as many as 4 per cent. although I have tried to select my cases with more or less care, picking out those whom I thought might be fit subjects, and not wasting my time upon those who would resist it from natural causes or inclination. That hypnotism is possible goes without argument; that crimes may be due to hypnotism I think is in all probability equally a fact. Dr. Bernheim, who has been quoted this eveding, on one occasion in Paris went into the various hospital wards where he selected hypnotizable subjects and made suggestions after this order: he would tell them that on a certain occasion at a certain place and certain hour they saw a crime committed and he would detail the incidents of the crime and also tell them they would be called before a magistrate and asked to testify. In the next ward he would give the same suggestions from a little different standpoint, and in that way hypnotized several witnesses, being careful not to tell any one of them exactly the same story, so that the appearance of collusion would be eliminated. The next day these men were brought before a judge and each told the story suggested to him with all the circumstantial details necessary, had the facts justified it, to produce a conviction. In other instances insignificant crimes have been committed upon hypnotic suggestions, and that a serious crime might be committed I think must be admitted. But it is to be kept in mind that extremely few subjects are so hypnotizable that a deliberate crime after a considerable lapse of time could be carried out by them even if it had been suggested.

If it were not another story, I would like to take up this question of legal and moral responsibility and the right and wrong test which has been laid down in the McNaughton case and has been servilely followed by the legal profession ever since.

I wish in closing to call your attention to some resolutions adopted in 1876 by this Society, strongly advising against all publie demonstratious of hypnotism.

Dr. D. T. Nelson:-I am interested in this subject but $I$ confess $I$ don't know anything about it and I am very much of the opinion that those who know most about it know very little. I am very much obliged to the essayist for giving us so much of his research, experience and suggestion.

Dr. E. J. Doering :-Some ten years ago I felt a good deal like Dr. Sanger Brown about hypnotism. You will recollect that a member of the Chicago Medical Society made some interesting experiments before the society on half a dozen subjects. A little later I was one of a committee to investigate the subject and it was found that they were all socalled "horses." But after witnessing some extraordinary experiments last year in Charcot's clinic at Paris, I am very much interested in the subject as illustrated in the admirable paper presented by $\mathrm{Mr}$. Brown to-night.

I also want to say a word about expert testimony. I most cordially agree with Mr. Brown, and I think physicians as a rule, outside of those who are particularly interested in expert fees, feel very much as Mr. Brown does, that, wholly independent of the fee, the ends of justice would be more quickly served.

Dr. Samuel J. Jones:-I am too unfamiliar with the sub- 
ject to express any opinion in regard to hypnotism, and I can only say as far as expert testimony is concerned, that it is a matter which appeals to all in the medical profession as well as in the legal profession. I feel that we cannot advocate that question too much until we obtain a point more definite, more satisfactory, approaching more nearly to justice both to those concerning whom testimony is given, and those who are called upon to testify.

Dr. D. R. Brower:-I have made, in the last eight or ten years at Chicago and elsewhere, a good many attempts at producing this hypnotic state that the essayist has so admirably described, and I am free to confess that I am not an expert in the hypnotic art. I have found an exceedingly small proportion of people who could be brought into this condition, and this proportion among native born exceedingly small. The only really good subjects I have ever succeeded in finding were among the French, and not our Canadian French, but French from France, and they have been almost always females. There is something peculiar about the construction of the nervous system of a Frenchwoman that makes her to a very much larger degree susceptible to this influence that $I$ have never found among our own people; indeed, I have rarely, if ever, succeeded in producing the hypnotic state in a native American unless it happened to be a child of twelve or fourteen years of age and then I had very great doubts as to the genuineness of the performance, so I don't believe there is any such cause of alarm as would seem to be indicated by the paper. I think the proportion of negroes who are susceptible to this hypnotic influence is very large, greater even than the French, and it may be that there is danger of suggesting crimes to them. Where a person is susceptible to hypnotic influence, I believe it is possible to make suggestions to them of a criminal character; and I am well aware of another fact, that if you have once succeeded in inducing this hypnotic condition it is an easy matter to repeat it, and the more frequently it is repeated the easier it is. So I think that while the French may have reason to be alarmed, so far as we are concerned in this country there is not much cause for fear.

Upon the question of expert testimony, I quite agree with the essayist, I think we have some of the most disagreeable presentations of questions at courts that can be imagined. Just what the remedy is I don't know, it may not be in the direction he has suggested, but certain it is that our methods of expert testimony, so-called, are a disgrace to the medical profession. I am free to confess that I differ most emphatically from the definition of responsibility that $m y$ distinguished and personal friend, Judge Tuthill, has given us. I think there must be something more, something very much more, than the mere knowledge of right and wrong to establish this question of responsibility. The insane man may know perfectly well the difference between right and wrong and yet commit a criminal act and not in $\mathrm{my}$ judgment, be responsible for it. The narrow limits of responsibility that were set up in the McNaughten case will not apply. In scientific psychiatry there must be the power to do what is right as well as the power to know what is right, there must be power as well as knowledge.

Judge Richard S. Tuthill :-I do not think I disagree with the chairman very much in his idea; $I$ think that people are insane who really know the difference between what is legal right and legal wrong, but I think such people should be restrained and that they should be held accountable for their actions, not on their own account, but on account of the community.

Mr. E. O. Brown, in closing the discussion, said: I don't know that Judge Tuthill and I disagree so much if we could only eliminate the unnecessary part of what each of us has said. I thoroughly agree with him that it is not every man who is in an abrormal state of mind that should be acquitted of crime if he be put upon trial for that crime, and the crime is proven to have been committed by him It does not seem to me that the mere fact that his mind is disordered should be sufficient to acquit him. But the trouble in Judge Tuthill's argument is in limiting the state of mind which should acquit him or which should prevent his being stigmatized as a criminal, to his knowledge of whether the act was right or wrong; now I doubt whether that is true. The deliberate opinion of the very high authority in English law in the McNaughton case was that that was the test, and that alone; but I do not think it is presumptuous to say that that rule has never given satisfaction to the lawyers or the bench either in England or America, and has been thrown aside-not absolutely denied. but not followed, and treated with very much less consideration than one would suppose a rule enunciated by such high authority would be in a pro- fession that follows precedents so closely as does the law. Most of the aequittals - and I think Judge Tuthill will agree to this-of persons in this country and England, upon the ground of insanity, have been where the real question was that of uncontrollable impulse, or impossibility to control the conduct, rather than the want of knowledge of right and wrong.

As to the matter of hypnotism, I was very much pleased to hear what has been said about it by the physicians, and I should have liked very much to have heard something more about Charcot's clinic, because it has always seemed to me that these experiments conducted in Paris under Charcot's immediate supervision, have been the most convincing of any of the phenomena that hypnotism has presented. I quite agree with our presiding officer that the danger of criminal suggestion is not so great here as it is in France, but it does seem to me that with the extension of knowledge among all classes of people as to the possibilities of hypnotism, and the fact that we have among us a population not Anglo-Saxon but largely Celtic, and that we ave a negro population which is very amenable to such influences, and that children of all races are peculiarly susceptible, makes it necessary, not that we should become panic stricken about it, not that we should take any extreme measures, but that we should look earefully at the rules and practices which prevail in our courts, in order that we may reform those things which are present abuses, and which will be abuses of more importance and of more far-reaching bad results if these problems of hypnotism are to be thrown upon the courts. That is the connection which I made beween this matter of expert testimony and the main subject of the paper. It seems to me that we do not now have to propose any practical measures to ward off the dangers of hypnotism, but to consider that there are new questions of responsibility to add to the perplexities which the courts already suffer from in the matter of alienation; that we ought to be looking about to see whether the rules and practices which now prevail are according to right and reason, or whether they can be improved upon; and I must say that the medical profession ought to take very advanced and energetic action in this matter, because-with regret $I$ say it-the lawyers never will.

\section{SECTION ON PHYSIOLOGY AND DIETETICS.}

\section{RECORD OF MINUTES.}

Tuesday, June 7.

The Section met at 3 Р.м., Dr. Kleinschmidt in the chair. P.M.

Wednesday, June 8.

Section called to order 3:30 P.M. Records read and accepted.

The Chairman then delivered his address on "Physiology," culling from publications in many languages the progress made during the year. which was very remarkable and of intense interest, for the contributions shed new light on functions and some of them,-especially as to the cerebellum were revolutionary in medicine.

The thanks of the Section were voted to the chairman for his unusually able and timely resume.

Pavers also were read as follows: On the Navy Ration by Assist. Surgeon C. A. Siegfried U.S. N.; on the Marine Ration by Dr. G. W. Stoner, Marine-Hospital Service, and on The Army Ration by Assist. Surgeon C. E. Woodruff, U. S. A. The thanks of the Section were accorded to these gentlemen through the Secretary.

The time consumed was about three hours and then the Section adjourned to 9 A.M., June 9 .

\section{Thursday, June 9.}

Met at 9 A.M. Discussion of the Army, Navy and Marine Rations.

The Secretary said that he was in favor of testing foods singly fed with water, tea or coffee as drinks, flavored or not with lemon juice,-under military or naval discipline, in order to get at the best foods for the service. Assist. Surgeon Seigfried said that nothing could be done with soldiers or sailors outside of the rations more than with civilians unless they volunteered and were paid extra for it.

The Secretary thought that a wheat sausage would be far 